\title{
The Effect of Talking Stick Learning Model Toward Students' History Learning Outcomes
}

\author{
Mariah $^{1)}$, Sarkadi $^{2}$, Nurzengky Ibrahim ${ }^{3)}$ \\ Historical Education Study Program of Postgraduate Universitas Negeri Jakarta ${ }^{1,2,3)}$ \\ ali.maria49@yahoo.com ${ }^{1)}$, sarkadi@unj.ac.id ${ }^{2)}$, nurzengkyibrahim@yahoo.ac.id ${ }^{3)}$
}

\begin{abstract}
This eksperimental study aims to determine the effect and difference of talking stick learning. The research design used was posttest-Only Control Group design. The population in this study amounted to 78 students. Sampling technique uses cluster random sampling. This study uses a sample of two classes. Data collection methods using test and documentation. Data analysis using simple regression test and independent sample Ttest test using SPSS 19.0. the result of the analysis of simple regression test data are $t$ count> table, so Ho is rejected and Ha is accepted which means that there is influence of the use of cooperative learning model talking stick type on history studies learning outcomes of XI grade students of Pelita high school three. The result of analysis of independent sample $\mathrm{t}$ test tess data are $\mathrm{t}$ count $>\mathrm{t}$ table, so Ho is rejected and Ha is accepted which means that there is a difference in the use of cooperative learning model talking stick type on history students learning outcomes of XI grade students Pelita high school three.

Keywords: Talking Stick model, learning outcomes.
\end{abstract}

\begin{abstract}
Abstrak. Penelitian eksperimen ini bertujuan untuk mengetahui pengaruh dan perbedaan pembelajaran Talking Stick. Desain penelitian yang digunakan adalah desain post test kontrol grup. Populasi dalam penelitian ini berjumlah 78 siswa. Tekhnik pengambilan sampel menggunakan tekhnik random sampling. Penelitian ini menggunakan sampel dua kelas. Metode pengumpulan data menggunakan tes dan dokumentasi. Analisis data menggunakan uji regresi sederhana dan uji sampel independen Ttest menggunakan SPSS 19.0. Hasil analisis data uji regresi sederhana adalah $t$ hitung $>$ tabel, sehingga Ho ditolak dan Ha diterima yang berarti ada pengaruh penggunaan model pembelajaran kooperatif tipe talking stick terhadap hasil belajar Sejarah siswa kelas XI IPS SMA Pelita Tiga. Hasil analisis data uji $\mathrm{t}$ sampel bebas adalah $\mathrm{t}$ hitung $>\mathrm{t}$ tabel, sehingga Ho ditolak dan Ha diterima yang berarti ada perbedaan dalam penggunaan model pembelajaran kooperatif tipe talking stick pada hasil pembelajaran Sejarah siswa kelas XI IPS SMA Pelita Tiga.
\end{abstract}

Kata Kunci: Model Talking Stick, Hasil belajar. 


\section{INTRODUCTION}

The development of increasingly modern times in the era of globalization demands quality human resources (Sintong, 2013). Increasing human resources is an absolute prerequisite for achieving development goals. One way to increase human resources is through education. The nature of education is a process of change relating to behaviour in a positive direction because education will bring people to themselves become dignified people (Hasan, 2012). Education is also a conscious effort to grow and develop the potential of human resources through learning activities. The National Education System Law No.20 of 2003 states that national education aims to educate the life of the nation and develop Indonesian people as a whole, those who are devoted to God Almighty and virtuous character, have knowledge and skills, physical and spiritual health, personality steady, independent and responsible for society and nationality. (Law No. 20,2003) Based on the purpose of education, it appears that the learning of students is not just about teaching knowledge alone. The law has laid strong foundations in sustaining the development of national character and identity (Rudyanto, 2014). One effort to improve the quality of education in schools is by way of improving the learning process. Various new concepts and insights about the learning process in schools have emerged and developed in science and technology. In the implementation of learning the skills required by teachers are the ability to manage teaching materials and the ability to choose approaches or methods, media and learning resources. A teacher can achieve optimal results in the learning process if the teacher as an educator is able to use methods and selection of appropriate learning models.

Learning activities will lead to changes in behaviour through learning activities (Pane \& Darwis Dasopang, 2017). Therefore, instructors, trainers, and teachers are one of the determinants of the success of student learning processes. The teacher's task is not only transferring knowledge alone (Tety Marzukhoh, 2017), but also helps students to have the desired competencies (Balqis, Usman, \& Ibrahim, 2014), and can implement and internalize positive values in real life.

Based on preliminary studies conducted by researchers at Pelita Tiga High School when learning activities took place students appeared not to be in a position ready to receive subject matter, as evidenced by their unstable sitting position and even leaning their heads on a table or a wall, chatting with their peers even some are busy copying other subjects or doing homework (homework). Learning is delivered using the lecture method so students get bored quickly. From some of the facts above, it is suspected that the Minimum Mastery Criteria, especially in the history lessons which are imposed on students 
become less able to be achieved. By looking at these facts it is necessary to develop varied teaching methods that can reduce students 'boredom in receiving lessons and can improve students' ability to interact socially and minimize differences in class. One of the alternatives taken to improve student learning outcomes is through the creativity of the teacher in selecting and determining learning models. The current education system requires students to be active, creative, and innovative in responding to every lesson taught. So the teacher is required not only to explain the things contained in the book but to understand, encourage, inspire and guide students more enthusiastically in an effort to achieve the goals to be achieved. Therefore social studies lessons can be delivered with other alternative learning models, namely cooperative learning models. The cooperative learning model is a learning model in which students are grouped into small groups consisting of 4-6 students to solve a problem, complete a task to achieve a common goal (Trianto. 2012; Fathurrohman 2015). To achieve these goals, students in cooperative groups help each other to make students more active in learning, have a good ability to think critically, work well together and be able to accept differences that exist between friends of one group so that students feel more comfortable and motivated to achieve higher learning outcomes.

The purpose of high school history learning is required to lead to an in-depth understanding of various events that are considered important to build critical thinking skills, creative thinking (Yusuf Budi Prasetya Santosa, 2017), learning ability, curiosity (Rudyanto, 2014), social awareness, and enthusiasm nationality. Historical subjects are accommodated in the curriculum as subjects that must be taught at the high school level. The curriculum includes written plans and reflects the implementation of learning in schools.

Learning history should be able to require students to develop competencies to think chronologically, critically, and creatively so we need a creative and innovative learning model which is then applied by educators to increase the motivation of students in learning history and ultimately students get good learning outcomes according to with the aim of learning history (Lestari, 2017). Each learning model has strengths and weaknesses. The following are the strengths and weaknesses of the Talking Stick type of cooperative learning model. Shoimin (2012: 194) states the talking stick learning model has the following advantages: (1) Testing the readiness of students in learning; (2) Train students to understand the material quickly; (3) Encouraging learners to be more active in learning; and (4) Students dare to express their opinions. And the weaknesses of the Talking Stick learning model are as follows: (1) Making students exercise heart; (2) Students who are not ready cannot answer questions; (3) 
Making students tense; and (4) Fear of questions that will be given by the teacher. While the lack of a talking stick learning model is that if there are students who do not understand the lesson, students will feel anxious and worried when the stick's turn will be in their hands (Aqib, 2013). Based on the opinion of the experts above, there are various advantages and disadvantages in the talking stick learning model, therefore the teacher must facilitate students, guide and motivate students so that the talking stick learning model is successfully applied to students in accordance with expectations in the learning objectives. Talking type cooperative learning model is expected to be able to overcome the shortcomings and obstacles in the social studies learning process so that student learning outcomes in social studies improve and learning objectives can be achieved (Kadek, 2016). Based on the description above that the selected learning model is very influential in learning outcomes, especially in social studies subject matter.

\section{RESEARCH METHODS}

The research method used in this study was an experimental research regarding this experimental method Sugiyono explained that "The experimental research method could be interpreted as a research method used to look for the effect of certain treatments on others under controlled conditions". This method was used on the consideration that the nature of experimental research was trying out a learning model to determine the effect or effect of a treatment (Baharudin and Wahyuni, 2012). Experimental research was unique in two very important respects. This research was the only type of research that directly tries to influence. a certain variable, and when it was properly applied. This research was also the best type of research in testing the hypothesis of causality or causality. Therefore, experimental research was closely related in testing a hypothesis to look for influence, relationships, and differences in changes to the groups subject to treatment.

The research design used in this study was true experimental design using the Posttest Only Control Design. Sugiyono (2015) states that true experimental design (experiments that are really), because in this design, researchers could control all external variables that affect the course of the experiment. The samples used for the experiment as well as the control group were taken randomly from certain populations. So its characteristic was the control group and the sample was chosen randomly (Sugiyono, 2015). So after following the subject matter, the researcher gave a posttest question. Posttest was given two times in two meetings.

The population in this study were all students of class XI IPS Pelita Tiga High School consisting of 3 classes ranging from class XI IPS 1 to class XI IPS 3 with a total of 78 students, both male and female students. 36 
male students and 42 female students. Based on the research design that the authors used in this study, the authors needed two classes as research samples.

The sampling technique that researchers used in this study was cluster random sampling. According to Arikunto (2013) also explained that Cluster Random Sampling was a sampling technique based on a group that had been determined by a population member. Thus the sample taken was not carried out directly on all students, but in the class as a group.

The steps of the talking stick learning model are as follows (Jamiah \& Surya, 2016).

a. The teacher prepares a stick.

b. The teacher divides students into groups of 5-6 students in groups.

c. The teacher conveys the main material to be studied, then gives the opportunity for students to read and study the material.

d. After completing reading the material / textbooks and studying them, students close the book.

e. The teacher takes a stick and gives it to students, after that the teacher gives questions and students who hold the stick must answer it, and so on until most students get a part to answer each question from the teacher.

f. The teacher gives a conclusion.

g. Evaluation.

h. Closing.

\section{DISCUSSION}

Historical learning outcomes data obtained were then analysed, but before the prerequisite test analysis was carried out first, namely the normality test and homogeneity test. Data normality test is used to find out whether the distribution of research data on each variable has spread normally or not.

Data Normality Test uses the Shapiro Wilk Test, because the observed data is less than 50. The steps used in the Shapiro Wilk test are as follows:

1. Formulate a hypothesis

H1: data is normally distributed

H0: data not normally distributed

2. Determine the level of significance $(\alpha)$ of 0.05

3. Determine the Testing Criteria

$\mathrm{H} 1$ is accepted if the probability value $>\alpha$, $\mathrm{H} 0$ is rejected if the probability value $<\alpha$.

4. Draw conclusions

$\mathrm{H} 1$ is accepted if the probability value $>\alpha$, then the sample is normally distributed $\mathrm{H} 0$ is rejected if the probability value $<\alpha$, then the sample is not normally distributed.

If the data is normally distributed, hypothesis testing in a study uses paired sample t-tests and two independent samples. However, if the data studied is not normally distributed, hypothesis testing can be done with the Wilcoxon test.

a. Homogeneity Test. Homogeneity test is used to determine whether the two samples taken have the same data variant or not. 
Homogeneity is one of the recommended requirements to be tested statistically, especially when using parametric test statistics such as t-test and f-test (Kadir, 2010). Homogeneity analysis in this study used the test of homogeneity of variance with the help of SPSS version 19.0 with the following criteria:

1. Ho = both groups have homogeneous variants

2. $\mathrm{H} 1=$ both groups have variants that are not homogeneous

The criteria of Decision-making:

1. If the value is significant or the probability value $<0.05$, it is not homogeneous

2. If the value is significant or probability> 0.05 , homogeneous

Referring to the explanation above, it can be interpreted that there are significant effects and differences in learning outcomes in social studies subjects between groups of students using the talking stick learning model with groups of students using conventional learning. The results of data analysis the magnitude of the influence of the talking stick learning model on learning outcomes is, 397 and the difference in learning outcomes using the talking stick learning model is greater than traditional learning indicated by an average value of $83.8281>80.9375$. The results of this study are in line with the opinion of Shoimin (2014) states that the talking stick learning model is one of the cooperative learning models. This learning strategy is carried out with the help of a stick, whoever holds the stick must answer questions from the teacher after students learn the subject matter (Shoimin, 2014). Supported by the benefits of the talking stick learning model according to Huda (2014) states, "this model is useful because it is able to test the readiness of children, in training to understand the subject matter quickly, and invites them to continue to be ready in any situation". So through this it will affect student learning outcomes.

The results of this study are in accordance with the opinions of Thacker and Friedman (2017) and Purwasih et al (2017) which reveal that the learning model makes the feelings that arise from within the study to be more open and interesting to be learned by them. Learning is a lifelong activity that involves physical and emotional reasoning that can be formed and achieve success if done happily. This opinion is also supported by the opinion of Isjoni (2007) states, that learning using the learning model is one of the learning strategies that help students to think critically and creatively in accordance with the learning objectives because it emphasizes the student's experience to solve social problems through steps and procedures problem solving thereby increasing the learning outcomes of History. That way they actively use the brain, either finding main ideas, solving problems, or applying what they have just learned into a problem that exists in real life. 
The results of test explain that the implementation of historical learning by using the talking stick learning model affects student learning outcomes. It was seen by the differences in student learning outcomes in groups of students who use the talking stick learning model. This can be interpreted, that when students follow learning activities using the talking stick learning model, the learning outcomes will be different learning outcomes with conventional methods. Means the hypothesis stating that the talking stick learning model can influence student learning outcomes.

\section{CONCLUSION}

Based on the research results obtained, the researcher suggests the following things: (1) Teachers can use cooperative models such as talking sticks, Jigsaw, Group Investigation (GI) and so on in learning activities so students can participate in historical learning activities with enthusiasm, active and happy so as to foster an attitude of cooperation, interaction, dare to ask questions, answer and express opinions so that student learning outcomes improve .; (2) Based on the results of this study that the Talking Stick learning model is very effective when applied in learning, the teacher in the learning process is expected to be able to use the talking stick type cooperative model or other cooperative models to help students be able to comprehend and explore historical subject material in depth with the fun learning method so that it affects student learning outcomes; (3) Educational institutions, especially Pelita Tiga High School students can add insight and knowledge to teachers about various types of cooperative models and teaching methods that can be used in effective and fun learning activities that will affect student interaction patterns, academic understanding and student learning outcomes that are increased.

\section{REFERENCES}

[1] Lestari, N. I. (2017). Pengaruh Model Pembelajaran dan Kemampuan Berpikir Kreatif Terhadap Hasil Belajar Sejarah Peserta Didik di SMA Negeri 30 Jakarta. Jurnal Pendidikan Sejarah, 5(1), 28. https://doi.org/10.21009/jps.051.04

[2] Anggraini, I. G. A. M. D. (2013). Pengaruh Model Pebelajaran Kooperatif Talking Stick Berbasis Aneka Sumber Terhadap Hasil Belajar Ips Siswa Kelas V SD Negeri 5 DALUNG. 1-9.

[3] Atika, N. T., Wakhuyudin, H., \& Fajriyah, K. (2019). Pelaksanaan Penguatan Pendidikan Karakter Membentuk Karakter Cinta Tanah Air. Mimbar Ilmu, 24(1), 105-113. https://doi.org/10.23887/mi.v24i1.17467

[4] Balqis, P., Usman, N., \& Ibrahim, S. (2014). Kompetensi Pedagogik Guru Dalam Meningkatkan Motivasi Belajar Siswa Pada SMPN 3 Ingin Jaya Kabupaten Aceh Besar. Jurnal Administrasi Pendidikan Pascasarjana Univeritas Syiah Kuala, 2(1), 25-38. https://doi.org/10.1093/rfs/hhn039

[5] Djaelani, H. M. S. (2013). Peran Pendidikan Agama Islam Dalam Keluarga Dan Masyarakat. Jurnal Ilmiah WIDYA, 1(2), 2-6.

[6] Gunawan, I. (2017). Taksonomi Bloom Revisi Ranah Kognitif: Kerangka Landasan Untuk Pembelajaran, Pengajaran, Dan Penilaian. E-Journal.Unipma, 7(1), 1-8. Retrieved from http://ejournal.unipma.ac.id/index.php/PE 
[7] Hidayah, I. (2018). Peningkatan Pemahaman Biografi Tokoh Pada Masa Hindu Buddha Dan Islam Di Indonesia Melalui Model Pembelajaran Kooperatif Tipe Two Stay Two Stray (TSTS). Elementary School of Education E-Journal, 2(2), 1-33. Retrieved from

jurnal.untad.ac.id/jurnal/index.php/ESE/articl e/download/2827/1919

[8] Hamzah B Uno, M. K. (2015). Variabel Penelitian dalam Pendidikan dan pembelajaran. Jakarta: PT. Ina Publikatama.

[9] Haryanto, S. d. (2011). Belajar dan Pembelajaran. Bandung: PT Remaja Rosdakarya.

[10] Jamiah, R., \& Surya, E. (2016). Pengaruh Model Pembelajaran Talking Stick Dengan Metode Math Magic Terhadap Hasil Belajar Matematika Pada Pokok Bahasan Kubus Dan Balok Di Kelas V SD Negeri 200211 Padang Sidimpuan. AXIOM, 2(2), 244-255.

[11] Lie, A. (2010). Cooperative Learning (Mempraktekan Cooperative Learning di Runag-ruang Kelas). Jakarta: Grasindo.

[12] Muljono, D. d. (2004). Pengukuran dalam Bidang Pendidikan. Jakarta: PPS UNJ.

[13] Ni Ketut Trianti, L., Rini, K., \& Ni Nyoman, G. (2017). Pengaruh Model Pembelajaran Talking Stick Berbantuan Lagu Daerah Terhadap Hasil Belajar IPS. International Journal of Elementary Education, 1(4), 290297.

[14] Putra, S. R. (2013). Desain Evaluasi Belajar Berbasis Kinerja. Jogjakarta: Divva Press.

[15] Pane, A., \& Darwis Dasopang, M. (2017). Belajar Dan Pembelajaran. FITRAH:Jurnal Kajian Ilmu-Ilmu Keislaman, 3(2), 333. https://doi.org/10.24952/fitrah.v3i2.945

[16] Putu Lisdayanti, N., Kt Ardana, I., \& Suryaabadi, Bg. (2014). Pengaruh Model Pembelajaran Kooperatif Talking Stick Berbantuan Media Gambar Terhadap Hasil Belajar Ipa Siswa Kelas V Sd Gugus 4 Baturiti. Journal Mimbar PGSD Universitas Pendidikan Ganesha Jurusan PGSD, 2(1).
[17] Rows, A. (2014). Apa Guna Sejarah. Depok: Komunitas Bambu.

[18] Rusman. (2011). Model-model Pembelajaran Mengembangkan Profesionalisme Pendidik. Jakarta: PT Raja Grafindo Persada.

[19] Rusman. (2011). Model-model Pembelajaran Mengembangkan Profesionalisme Pendidik. Jakarta: PT Raja Grafindo Persada. 